\title{
Stunts and Plebiscites
}

\section{A VALENTINE TO VALENTINO}

The promotional work that Howe, Glyn, and Ullman performed for Valentino in fan magazines and trade journals expectedly informed how the country's syndicated press covered the actor's success and tribulations. The least chronicled promotional initiatives about Valentino were the publicity stunts, which critically accompanied the final months of his short professional life. One of Hollywood's most inventive and best-paid publicity men, Harry Reichenbach, had pulled off an earlier and rather small-scale one, which nonetheless anticipated more significant tricks. In the fall of 1924, Reichenbach was working for Famous Players-Lasky, which was about to release A Sainted Devil. He asked Valentino to grow a goatee for his forthcoming role during the ill-fated European preproduction of The Hooded Falcon. Upon returning to the United States in mid-November 1924, Valentino surprised everybody by sporting never-before-seen whiskers. Shortly afterward, Reichenbach went to the annual convention of the Associated Master Barbers of America in Chicago where he found a way to address the convention. Once on stage, he announced in alarm that Valentino had returned from Europe with unwelcome new facial hair: if it were to become popular in America, it would threaten the members' livelihood. Reichenbach then lobbied for a resolution "that called for nothing less than a boycott on all Valentino pictures until Rudy shaved off his beard."

In its coverage of Valentino's sudden change of appearance, Photoplay also published a sonnet and a drawing condemning the Divo's decision and insisting that he return to his old image. Its author, Margaret Caroline Wells, first revealed her shock before wishing for a complete return to normalcy: "Hed better see a barber and be the same old sheik. [...] We want our Valentino just as he used to be."2 The accompanying drawing illustrated the whiskers' unnatural appearance by showing how Fairbanks, Chaplin, Keaton, Harold Lloyd, William S. Hart, and an unspecified flapper would look with them (figure 25). While news of his beard continued to be printed for months in American newspapers, by December 21, 1924, Valentino had shaved it off. ${ }^{3}$ This stunt did not remain a well-kept secret. As a Photoplay profile revealed a year later, Reichenbach had persuaded Valentino to grow a beard "to cause a bad reaction that was followed by a good one when he 'agreed' to shave it." 4 


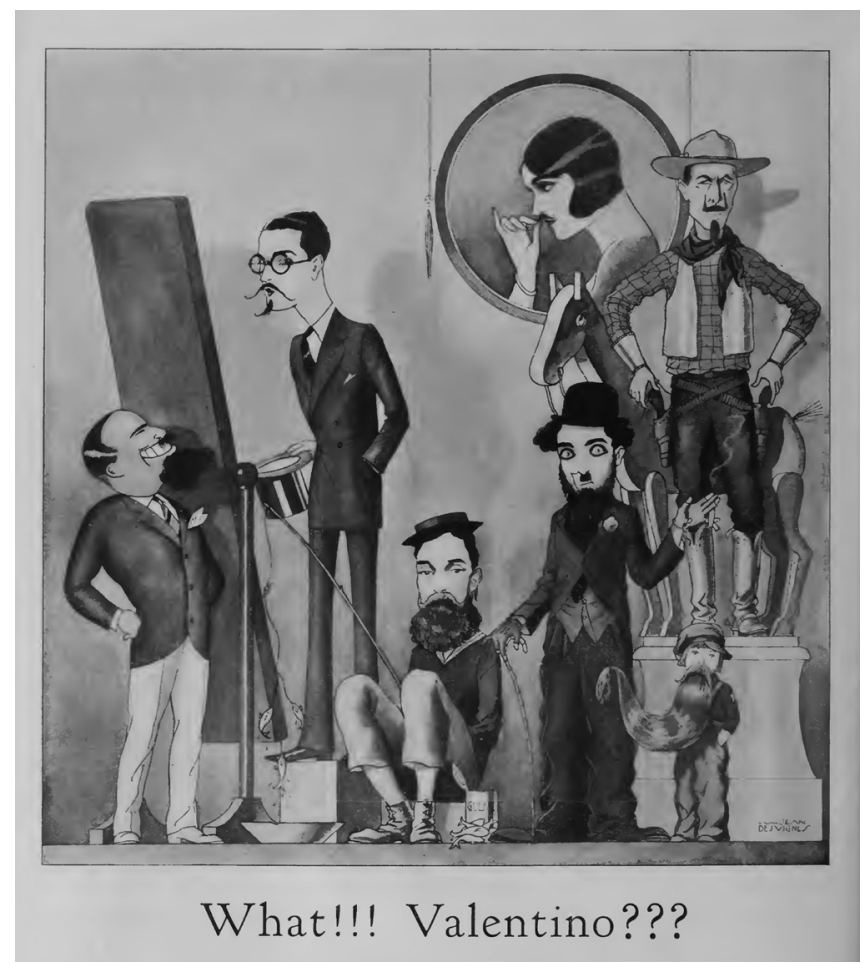

FIGURE 25. Illustration inspired by Valentino's new goatee. Margaret Caroline Wells, "What!!! Valentino???”, Photoplay, February 1925, 72.

The most important stunt, however, occurred, during the days preceding the premiere of The Son of the Sheik. United Artists chairman Joseph M. Schenck faced a marketing challenge. For Valentino to regain his unique popularity, the actor had to appear different from other Latin lovers, including Ramon Novarro and Antonio Moreno. Schenck viewed the adaptation of Hull's sequel, The Son of the Sheik (1925), as a great opportunity to do just that. In the film, Valentino played both father and son, and the cast included Agnes Ayres, who returned in the role of Diana, Ahmed's wife. The figure of the son, described "Young Chief" and "displaying a firm, obstinate chin and a straight, somewhat cruel mouth," brought back the untamed wildness of the original Sheik. ${ }^{5}$ Beyond the promotional opportunities of the narrative, the film had to be sold to distributors who were skeptical of the Divo's enduring commercial appeal.

Before the mid-1920s, Valentino's sophisticated manners, not to mention his history of dependence on strong women, had met with some criticism, even indignation, but always with a good dose of irony-as if these reactions were a ruse. Miriam Hansen recognized the performative dimension of these denunciations 
of deviance and suggested that they "were part of the ritual," perhaps "self-ironic," certainly "performing a rhetorical role" in a discourse "presumed to speak for all men." ${ }^{\text {At }}$ the time, however, there had been serious reactions to printed rumors aimed at minimizing the actor's difference from mainstream American masculinity. "There is nothing repellent, nothing unmasculine about Valentino," Willis Goldbeck of Motion Picture Magazine had written in the spring of 1922, "merely a heavy exoticism, compelling, fascinating, perhaps a little disturbing, as might be asphalt to the average cobbler." Still, as Mark Lynn Anderson has compellingly discussed, "Valentino's star presentation and his appearance within a mass cultural context [...] helped establish a queer space for the reception of mass culture." ${ }^{\text {For }}$ Anderson, it was not just that his diversity encouraged "investigating the relations between sexuality and gender," but also that "stardom provided a rather startling number of points of similarity with the visible aspects of contemporary gay male culture in America's largest cities."

Anderson is quite right in positing that "the question of Valentino's queerness considered within the context of America mass culture is not [. . . about his individual sexual identity, but about the types of sexualities his stardom made possible, gratified, or otherwise indulged." 9 However, his argument that the actor's queerness ("radically queer star") was akin to the prebourgeois sexual culture of working-class New York-especially its immigrant quarters-deserves close scrutiny. In his attempt to show how it was possible that Valentino's indeterminate sexuality stood out for "its utter indifference to American middle-class culture," Anderson appears to reify both bourgeois and immigrant working-class cultures and project contemporary critical tropes of heteronormative sexuality onto the latter. ${ }^{10}$ While he is careful to point out that he is not idealizing working-class neighborhoods as if they were "immune from homophobia," he relies on George Chauncey's work on middle-class homosexuals' social and sexual interactions with the less prudish immigrants of the Lower East Side to posit that in New York's ethnic neighborhoods, there was a "relative lack of stigma" for a " "masculine" man who had sex with fairies or accompanied them on dates."

This argument should be measured against two counterfacts: first, New York's urban working-class culture in the 1920 s was not homogeneous but consisted of many immigrant subcultures with different views of sexuality and individual conduct. Secondly, Valentino and the promotional discourse about him, particularly regarding his alleged nobility and timeless Italianness, had consistently endeavored to distance the actor from Italian immigrants' largely unappealing bodies and culture. Unsurprisingly, his reception in Italian neighborhoods largely depended on generational differences. Young men were attracted to him not necessarily because their culture gravitated to a "queer space," but because he presented an admirable Italian path to Americanization that radically differed from Enrico Caruso's - who was the idol of the old guard. In his 1924 urban travelogue Around the World in New York, Konrad Bercovici noted: 
Since the advent of Valentino all the youth of Little Italy try to look as much as possible like the moving-picture hero, and to haunt the moving-picture studios of the city, having in their Americanization somewhat abandoned the desire to become grand opera singers. ${ }^{12}$

The older generations, particularly those who controlled the ethnic press, pushed back against the untraditional masculinity of the Italian star. Only after his death did they express pride in his Horatio Alger trajectory-a narrative that was barely mentioned by that press during his lifetime. ${ }^{13}$

It is in a framework nonetheless imbued with often-veiled references to queerness that historians have largely read the famous Chicago Tribune editorial published on July 18, 1926, as an index of both the actor's sexually ambivalent image and the anxieties he produced in 1920 s America. ${ }^{14}$ One of the most-repeated passages blamed Valentino for the installation of a face-powder dispenser in one of the city's new public men's room:

A powder vending machine! In a men's washroom! Homo Americanus! Why didn't someone quietly drown Rudolph Guglielmo [sic], alias Valentino, years ago? [. . .] Do women like the type of "man" who pats pink powder on his face in a public washroom and arranges his coiffure in a public elevator? . . Hollywood is the national school of masculinity. Rudy, the beautiful gardener's boy, is the prototype of the American male. Hell's bells. Oh, sugar.

Valentino responded twice to the editorial, both times from the pages of the Tribune's rival, The Chicago Herald-Examiner. The day after the "Pink Powder Puffs" editorial came out, he called the anonymous author "a contemptible coward" and challenged him to a boxing match:

You slur my Italian ancestry; you cast ridicule upon my Italian name; you cast doubt upon my masculinity. I call you, in return, a contemptible coward and to prove which of us is a better man, I challenge you [...] to meet me in the boxing or wrestling arena to prove, in typically American fashion (for I am an American citizen), which of us is more a man. [...] I do not know who you are or how big you are, but this challenge stands if you are as big as Jack Dempsey. ${ }^{15}$

In his second response, after his return to the Windy City from New York, he shamed the anonymous editorialist again and declared victory because the slanderer dared not reveal his or her identity. The fact that Valentino immediately issued "a public challenge to the cowardly writer to reveal himself," as Anderson acutely points out, has prompted "the public to understand the nature of the editorial in precisely this manner" - as a personal assault on the actor's virility and national origin. ${ }^{16}$

The identity of the editorial's writer has never been determined with any measure of certainty, and this authorial mystery has seemingly encouraged the same, recurring kind of culturalist interpretation, either as a display of homophobic hate 
or, in Anderson's analysis, as an index of an emerging queer space in American culture. ${ }^{17}$ Anderson in fact has perceptively rejected a reading of the editorial as a straightforward homophobic and racist attack and has instead identified in it a "playful sarcasm" and a certain "self-consciousness about its own overstatements." Namely, in a climate that was already pervaded by rhetorics of public scandal, Anderson has questioned whether the piece, despite its pretense of aversion, was actually scorning "those who were threatened by the actor's deviant masculinity." Or whether it was "a public 'outing' of Valentino by and for those who identified themselves as queers, or by and for those who participated in and were supportive of gay culture generally." ${ }^{18}$ While the editorial's tone certainly exudes a feigned sense of scandal and not clear-cut hatred, the contemporary critical principle that reads "gossip [as] often an act of resistance" does not completely explain its raison d'être. ${ }^{19}$ The archival record, in fact, tells a different story-the story of a successful stunt that exploited the scandalous queerness of Valentino's popular image to pretend to scandalize Valentino himself, his fans, and, most importantly, those who found him effeminate and indecent.

At the story's center is one of the industry's most talented publicity men, Victor Mansfield Shapiro, who, in 1916, had founded the Associated Motion Picture Advertisers (also known as the Association of Motion Picture Advertisers). ${ }^{20}$ Shapiro's papers, held in the UCLA Library's Special Collections, consist of public relations and promotional materials relating to the motion picture industry and include questionnaires, his own biography, scrapbooks, photographs, and tapes and transcripts of interviews. Shapiro had a major career as an independent publicity man for the Hollywood film industry and even met Valentino on the set of The Eagle (1925). In May 1926, he was hired by United Artists (UA) managing director Hiram Abrams to work on publicity for The Son of the Sheik. ${ }^{21}$ As UA's publicity man for Valentino, he seemingly ghostwrote many of the actor's articles published during his final months.

In his transcribed recollections, Shapiro at first expressed the sort of conventional thinking that emerged out of brainstorming sessions in UA's Publicity and Still Photography Departments. The sessions centered on "how to make Rudolph Valentino more acceptable to the men customers." Predictable tactics included the use of photographs of Valentino "sparring with Jack Dempsey," "horseback riding," and "playing polo with Doug Fairbanks." A more daring publicity idea was to "photograph him nude from the waist up" and then "invite lady reporters to interview him thusly during his athletic diversions." ${ }^{22}$ The punch line of these playthe-Sheik-card strategies was quite straightforward: "Use the catch line 'Men, why be jealous of Rudy Valentino?' You too can make love like he does. See 'Son of the Sheik.'" The obvious question, however, was whether these ideas would have garnered the "front page splash" that was needed to revive Valentino's career. ${ }^{23}$

As expected of a loyal Hollywood professional, Shapiro underplays the role of publicity. In several instances, he claims that publicity could not manufacture 
a star out of nothing. "The dramatic impact Rudolph Valentino had on womanhood was not created by a press agent. [. . . ] Press agentry did not manufacture Valentino's extraordinary attributes. Publicity merely called attention to them." ${ }^{24}$ Notwithstanding these disclaimers, Valentino offered inventive publicity potential. Still, Shapiro recalls that at first he followed conventional methods. From his New York base, he began collecting biographic profiles, which insisted on Valentino as "sensual with animal grace," requested photographic poses, and planned "also to make a film trailer of these activities with the title, quote, "The Physique of the Sheik." "25 He sent all this material to the press, first-run theaters, and pictorial outlets. "They only caused a ripple with the males." ${ }^{26}$ Then he recounted the episode of the "Pink Powder Puffs" article, which fell outside the scope of conventional thinking and achieved the ultimate goal of any publicity campaign: "get the opening." ${ }^{27} \mathrm{He}$ called it "a Valentine to Valentino." ${ }^{28}$

The impetus came from his boss, Abrams, who had started negotiating the distribution of The Son of the Sheik with Balaban and Katz, the largest theater chain in Chicago. It had rebuffed his offer of exhibiting rights, bargaining down the price since, it claimed, "Valentino didn't mean a thing in Chicago." This response prompted Abrams to ask Shapiro to devise a "publicity campaign unmatched in [Valentino's] career." ${ }^{29}$ "On July 1oth, 1926," Shapiro recounted, "Abrams suggested I send him the livest wire on my staff to do something about Valentino when he stopped over between trains in Chicago." Shapiro chose Jimmy Ashcroft, "a veteran skilled in necromancy of press relations and exhibitor convolutions," who was charged to leave New York for Chicago within two days and secure "something on the front page, something-anything, provocative and entertaining." On July 12, at Grand Central Station, Shapiro met Ashcroft for last-minute instructions. The two veteran publicists, Shapiro later noted, thought alike.

On July 19, when Valentino arrived in Chicago from Los Angeles, the Chicago Tribune had just published the infamous "Pink Powder Puffs" piece-which in Shapiro's papers is identified as "A," as in Exhibit A. ${ }^{30}$ Ashcroft showed it to the actor and began "stoking up [his] indignation." Then he handed Valentino's prewritten reply, (or "B," as in Exhibit B) to Hearst's Herald Examiner, the Tribune's archrival..$^{31}$ Anderson has noted that the quickness of the response helped others take the editorial seriously and thus effaced its ironic tone. Within a few hours, Hearst was putting Valentino's prepared response "over the wires, the wire service, to all twenty-six [of his] papers and his other outlets." ${ }^{2}$ Shapiro recounts that Ashcroft then wired him copies of both the editorial and Valentino's response. Shapiro responded by asking Ashcroft to "keep [Valentino] fired up" on the way to New York since Shapiro's assistant, Warren Knowland, was about to hop on the train in Harlem and brief him on what to do next before arriving at Grand Central Station.

Give him some printable catch lines, have him carry a copy of the novel Cellini, his next picture. We'll have, we'll have photos at the station, press conference at the hotel, 
with Prohibition's best handing out copies of, of Chicago editorial and Rudy's answer. Then it's up to ye gods, and ye gods it was [laughter]. ${ }^{33}$

Part of Shapiro's choreography was a dramatic police escort for Valentino from Grand Central to the Ambassador Hotel on Park Avenue and 51st Street, inevitably followed by dozens of journalists. On the morning of July 20, Shapiro updated his friend Lloyd "Red" Stratton of the Associated Press on the latest news and told him where Valentino was staying - a veiled promise of first, if not exclusive, access. At the station "the crowd surged but the station guards managed to wedge Rudy to his auto without having his clothes ripped off." Everything was prepared in advance. The police motorcycle escort "was arranged through Frank Sennett," a college pal. In the car, Shapiro finally met Ullman, and while they seemed to agree as to who was handling what (Shapiro, the "picture end of the publicity"; Ullman, "the personal matters"), in reality Shapiro was handling it all. At least that's how he tells it. It was his idea that "Rudy was to receive the press in his blue and green silk robe and purple pajama, for the benefit of the lady reporters [laughter]." ${ }^{34}$ By early afternoon the Associated Press and the Hearst syndicated newspapers were carrying the story. "From that moment the telephone rang incessantly. Every news outlet in town, fan and general magazines, foreign press, film critics, males and females, sport writers, called for and received personal interviews. More than a hundred correspondents by actual count paraded in and out of Rudy's hotel suite." 35

Shapiro has recounted the circumstances of Valentino fighting the sportswriter and boxing expert Franck "Buck" O’Neal on the hotel's terrace in front of a Pathé News cameraman. It was the promotional equivalent, as staged event, of Valentino's prepared response to the press. The 167-pound Rudy fought the 200-pound, sixfoot-one former fullback O’Neal and won. But if that was not enough, the news was what O’Neal repeated to the press: "Make no mistake. That guy throws a punch like a mule's back." "Why not print that," said Shapiro to his 1966 interviewer. That very line was included in an article, "Powder Puff? Wham!", that recounted the match. ${ }^{36}$ The news that Valentino wanted to challenge the anonymous editorial writer in staged fights that were nothing other than public relations stunts was the subject of satirical cartoons (figure 26). To close the circle, when Shapiro's man in Chicago, John Ashcroft, called him again, he reported that "stories were breaking front page there, that the Balaban and Katz crowd never, never again would say Valentino doesn't mean a thing there." ${ }^{37}$ Ashcroft also told Shapiro that Valentino, upon his imminent return to Chicago, would issue another statement to the anonymous "editor" of the Chicago Tribune.

In his reminiscences, Shapiro notes that eventually Ashcroft told him that "the writer who penned the Pink Powderpuff [sic] editorial was named John Glasscock" - a name that may well have been fictitious..$^{38}$ What is certain is that the whole initiative amounted, in Shapiro's words, to "the most extensive and intensive publicity break in Rudy's short life." ${ }^{39}$ Shapiro's description of himself and 


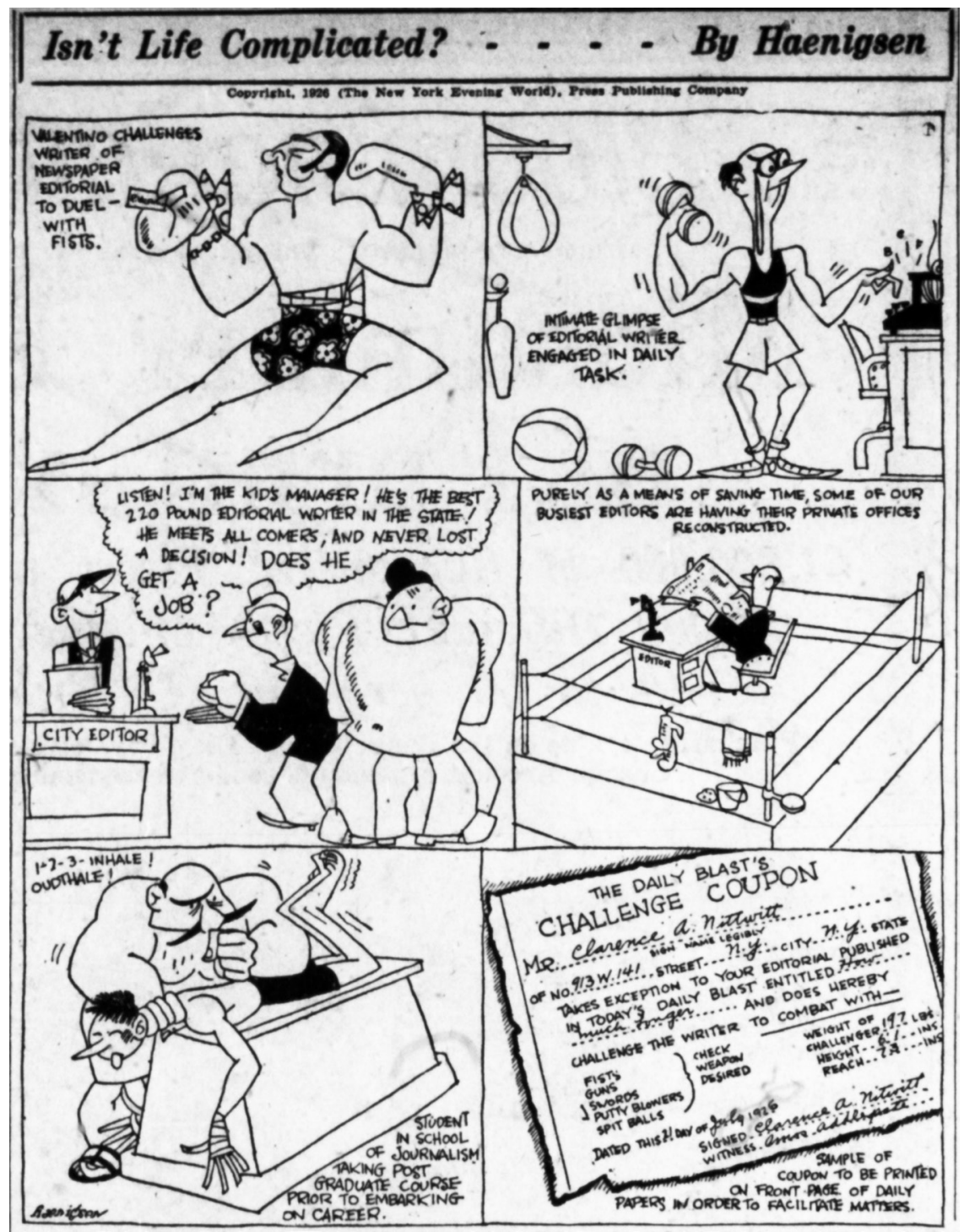

FIGURE 26. Cartoon depicting the prospect of a boxing match featuring Valentino as a major public relations event. Harry Haenigsen, "Isn't Life Complicated," Evening World, July 21, 1926, 16. 
Valentino as "more than passable actors" and his admission that Rudy indeed had a sense of humor and "was acting his resentment" appear to support the notion that the actor was a willing participant in the scheme. ${ }^{40}$

The result was an artful scandal. Mobs of spectators filled the Strand on Broadway for the film's opening. A few days later the same occurred in Chicago, where Valentino had returned as promised after presiding at the New York premiere. In front of a "cheering crowd swirling around the station," the actor, who was clearly on board with the stunt, exclaimed what Shapiro defined as his "Lafayette, I am here" statement. Before the crowd, he addressed the author of the offensive editorial, shouting: "Mr. Editor, I am here. I am ready. Where are you?" Thanks to the wires, his challenge went national in a few hours. ${ }^{41}$ At this point, Shapiro refers to "C" (as in Exhibit C), which was Valentino's second prepared statement to the press.

The heroic silence of the writer who chose to attack me without any provocation in the Chicago Tribune leaves no doubt as to the total absence of manliness in his whole makeup. I feel that I have been vindicated. ${ }^{42}$

In Chicago, Valentino also posed with several boxers while renewing his challenge, surrounded by a new kind of fan. The "continuous pink Powderpuff imbroglio," as Shapiro described it, "brought out what one writer said was 'a sporting audience known for its literary, dramatic, social and artistic distinction, a cross-section of Chicago's most cosmopolitan. " 43 After recounting similar triumphant processions occurring in Atlantic City, Shapiro mentioned that "leading trade papers publishers" Martin Quigley of Exhibitors Herald and Sam (a transcription error for "Sime," short for Simon) Silverman of Variety calculated the financial impact of this scheme. They allegedly told Shapiro that the Valentino campaign "must have garnered millions of lines of free space all over the world, which if purchased at regular advertising rates would exceed millions of dollars," not to mention adding a million dollars "to the box office gross on The Son of the Sheik." 44

After almost two weeks of front-page coverage, the "sensational Pink Powderpuff hullabaloo" had gained a strength of its own that even affected its architects. When on August 16 Shapiro, out of town, read in the papers of the actor's sudden hospitalization in New York, he thought it another ploy. "As a press agent somewhat immune to shock," he recalled, "I didn't believe it. Nonsense!" So he called his assistant, Knowland, fearing that he had been "pulling a stunt without [his] knowledge." 45 Valentino's sickness, however, was no stunt. Although Shapiro, Ullman, and UA hoped it would quickly pass, in the meantime they saw it as another publicity opportunity. Shapiro and Knowland went to the "press room at the hospital" and, even though Ullman was in charge of "personal publicity," the crisis called once again for a breach of contractual protocol: "Biographies and pictures of Valentino were passed out by Knowland." United Artists sought to install a press room in the hospital. ${ }^{46}$ Instead of recuperating, Valentino's condition only 
worsened after developing peritonitis and septic endocarditis following an operation for perforated ulcers. He died on August 23, 1926, to the apparent surprise of everyone-his fans, the studio, and his publicists. The latter group was the quickest to react to it in ways that would frame both his passing and afterlife.

\section{DEATH AND BALLYHOO}

Ullman and Shapiro and his men were not the only publicity people who followed Valentino's deteriorating health and sought to construct posthumous narratives that would exploit his story. Their efforts challenge the conventional opening of countless volumes and articles about Valentino, which regularly insist on fans' spontaneous and authentic display of mass grief, visible in some newsreel footage, following the actor's unexpected death. ${ }^{47}$ To contemporary Italian papers such popular displays amounted to a plebiscito di dolore (plebiscite of pain). In truth, the coverage of the actor's hospitalization, infirmity, and death was infused with publicity ploys aimed to spur fans to emotional displays, apparently out of control yet well choreographed, and present their affection for the Divo as unprompted.

Valentino's hospitalization, death, and New York funeral were a bonanza for all the city's papers from the Journal to the Evening World and The Telegram. During this time, the publicity stunts became also photographic. At the center of these efforts was the New York Evening Graphic, commonly known as the Graphic, a tabloid newspaper published from 1924 to 1932 by Bernarr Macfadden, which specialized in scandals and made-up news about celebrities. Beyond its mendacious stories, the Graphic managed to outsell competitors through a "brazen staging and manipulation of photographs" known as a "composograph." ${ }^{88}$ In late August, the Graphic published a composograph, made from twelve photographs, of Valentino being lovingly assisted by nurses while in the operating room that caused the Graphic's circulation to soar. It was just the beginning.

The Graphic's picture editor Frank Mallen recounts in his celebratory and often imaginative memoir, Sauce for the Gander, that when Wallace Reid and Olive Thomas died, "their pictures died with them" as "there was strong public sentiment and general disapproval of the exhibition of pictures after death." 49 Not so for Valentino. "[Frank E.] Campbell had made a deal with officials of United Artists," Mallen reports, referring to the prominent New York funeral director. "He told them that if they would let him handle the funeral, in the event of death, he would make Valentino's pictures more popular and profitable than ever." After United Artists accepted, Campbell solicited the Graphic's help. While Valentino's body was still at the Polyclinic Hospital, a composograph was being made of it as if it had already arrived at Campbell's funeral home. ${ }^{50}$ To the surprise of its editors, the Graphic was breaking records.

According to Mallen, the tabloid had negotiated a special relationship with Campbell's publicity aide, former reporter Harry C. Klemfuss. A "pioneer in the 
field of public relations and a master of the publicity stunt," Klemfuss assisted the press "by advance distribution of photographs and material regarding the chamber where the screen star's body would lie." ${ }^{51}$ The role of this New York publicity man is confirmed by Silas Bent in a chapter on free publicity in his 1927 book Ballyhoo. Bent notes that "around the undertaker's place of business were rioting mobs" and "the crowd stretched through eleven blocks of streets." ${ }_{52}$ Mallen recounts that Campbell and Klemfuss, "old hands at handling crowds," had a system in place to make sure that the crowds were kept at mob size and agitated: "The funeral church doors would be locked for twenty minutes out of the hour. This gave time for replacements to arrive at the rate of twelve for each one permitted to view the remains." ${ }^{33}$ Although a plate-glass window was smashed and several were injured, generally speaking the "mobs were photogenic and obliging, whether in formation or as individuals" (figure 27). They gladly became part of the show and "would turn in any direction and strike any pose as long as a camera lens was in front of them." ${ }_{54}$ As Bent saw it, Klemfuss viewed the result as "a minor triumph. The name of his client appeared four days successively on the first page of one newspaper, in addition to many tabloids, in 'fourteen-point type', and when he had noted a million lines of free publicity he quit counting." ${ }_{55}$ Both Bent and Mallen reported that, during the procession of Valentino from the funeral home to St. Malachy's Church on 49th Street, the Graphic managed to sell thousands of copies of a special edition featuring a front-page photograph of the very same procession! Mallen quoted Paul Gallico, from True magazine, describing the photograph as "the journalistic miracle of the ages." It was instead a composite photograph prepared a day ahead with mock pallbearers, a rose-bedecked coffin, and hired mobs. ${ }^{56}$

In the months following the funeral, the Graphic wanted to match its outstanding August 1926 circulation. When its editors heard of spiritual mediums contacting Valentino, who told them that he was "happy 'up there with the angels," the periodical resumed the Valentino composographs. Two, in particular, are worth mentioning. One shows Valentino upon his arrival in heaven; the other in the company of Enrico Caruso, who had passed away in 1921 (figure 28). They were constructed from, respectively, five and eight photographs. ${ }^{57}$ The latter scene had allegedly been described by a psychic, and the resultant Graphic story was sold for serial publication in early 1927 to the Doubleday Page Syndicate. It appeared on the frontispiece of Silas Bent's Ballyhoo. These two images solidified the perception of a close association between Valentino and the spiritualist tradition of séances that the actor frequently engaged in with his second wife..$^{8}$ More significantly, the miraculous new images prolonged his exploitation posthumously. ${ }^{59}$

Shapiro does not mention these publicity feats. Instead, to safeguard the star's direct appeal, he contended that Valentino's popularity needed "little propulsion or fanfare." After all, the actor's "screen portrayals, so real to so many, were his most potent press agent" and, Shapiro argued, "no press agent, no front-page publicity gave Valentino this indefinable something. He had what no other screen star ever 


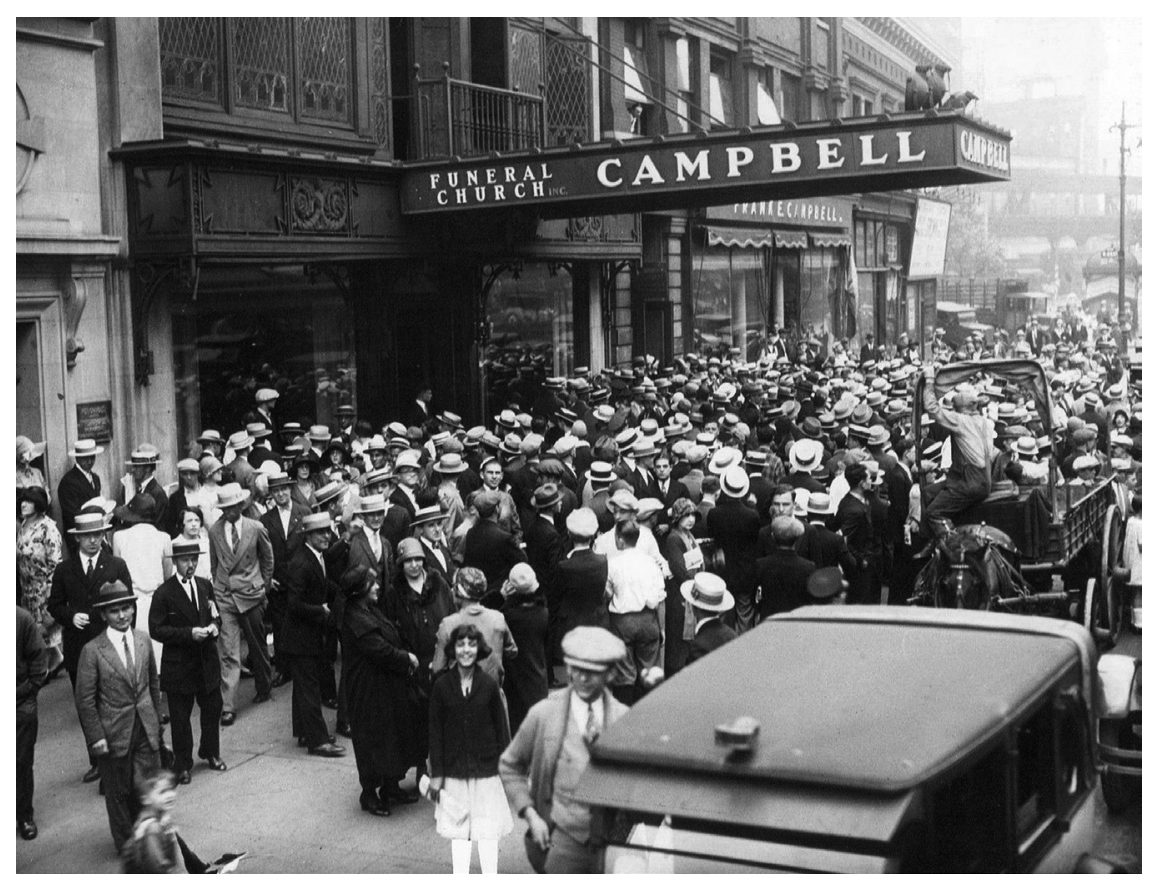

FIGURE 27. Crowd gathered outside the Frank E. Campbell Funeral Chapel, August 1926.

Photograph by International News Photos, a division of W. R. Hearst's International News Service.

had." ${ }^{\circ}$ One could argue that in light of the aforementioned queer overtones in the actor's public image, which the powder puff stunt had so effectively exploited, Shapiro's rhetoric conveniently divested studios and publicity agents from any moral responsibility over Valentino's reception. Following the many damaging scandals that characterized 1920s Hollywood, the studios had every interest in insisting that their stars' private lives constituted a domain over which they had no control. That way they could allege that Valentino's public image simply mirrored the alchemy of who he was and what his fans expected and desired.

Still, the "indefinable something" was more than just fame; it was also a form of authority over the masses, which in Shapiro's recounting justified the use of political attributes: "the newspapers covered the proceedings," he noted, "as they would in obsequies of president, prime minister or potentate." "No king in any realm was more revered or honored," Shapiro concluded rather bombastically. ${ }^{61}$ In doing so, he placed Valentino's widely publicized wake and memorial in relationship with another celebrated Italian figure in America, Benito Mussolini. Specifically, he referred to the clash outside Campbell's between New York-based Italian Blackshirts and Valentino's friends, who knew of his anti-Mussolini stance. The former claimed that they were paying homage to the actor by standing guard around his bier, allegedly on the Duce's orders. This incident requires a brief explanation. 


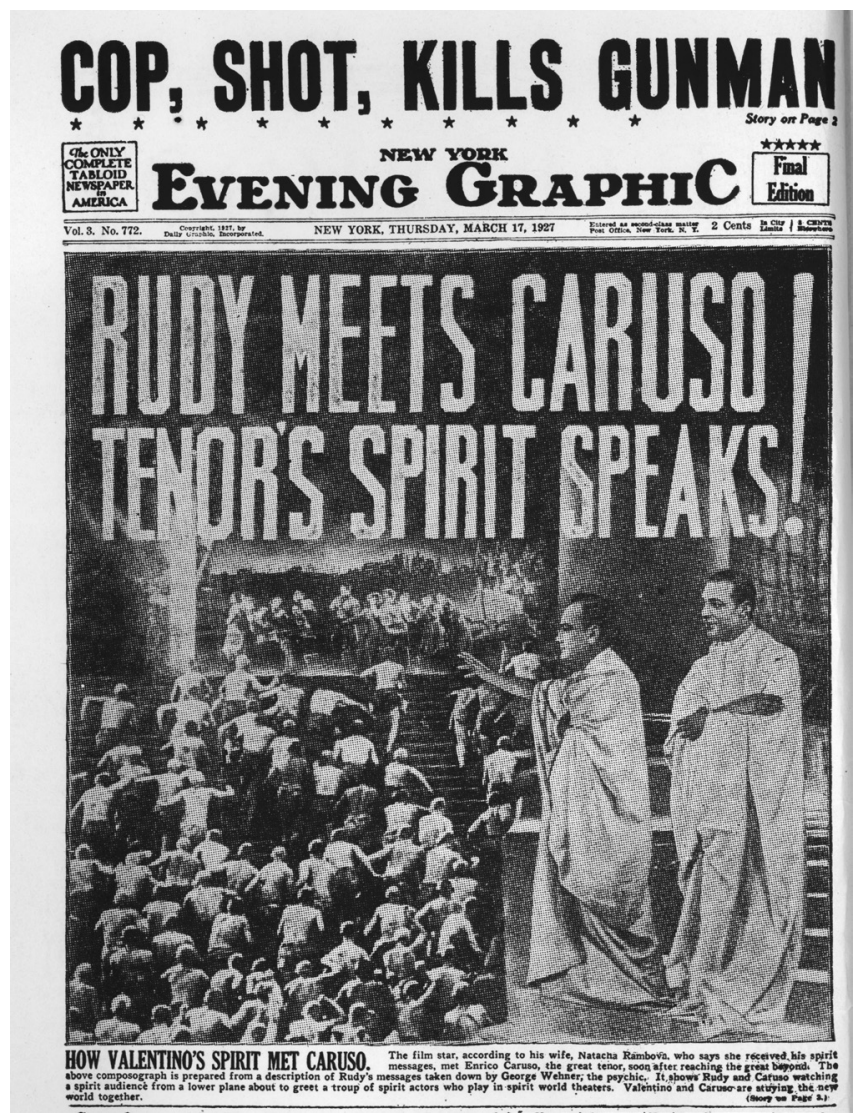

FIGURE 28. Valentino and Caruso in heaven. New York Evening Graphic, March 17, 1927, composograph.

After becoming a star, Valentino attracted little interest on the part of Fascist and anti-Fascist groups in both the United States and in Italy. In America, he had little contact with Italian American groups even after Mussolini's March on Rome in October 1922, about eighteen months after his breakout film, The Four Horsemen. In the old country, his films were for years invisible except in major cities. For a while, the Divo and the Duce coexisted peacefully in mutual indifference. In 1923, during Valentino's first trip back home, he stopped in Rome but he and Mussolini failed to meet. Mario Quargnolo has suggested that Valentino was close to collaborating with producer Arturo Ambrosio in 1924 on the film adaptation of Mussolini's 1909 novel L'amante del cardinale (The Cardinal's Lover). It would have been a publicity dream to sell a film written by the Duce and starring the Divo. ${ }^{62}$

But in late 1925, a public rift occurred. On November 10, while in New York for the opening of The Eagle, Valentino applied for U.S. citizenship, which the New York 
Times reported. ${ }^{63}$ At the time double citizenship was not an option: acquiring U.S. citizenship meant the relinquishing of Italian citizenship. The response of the Fascist regime was quick and negative. Castigated as a traitor, Valentino saw his films first boycotted and then banned in Italy between late November and early December $1925 .{ }^{64}$ Pressured by Paramount and United Artists, he wrote (or simply signed) a letter directed to his Italian critics, and thus Mussolini, in which he sought to explain his reasons. Entitled "Una lettera di Rodolfo Valentino, attore italianissimo," the letter was published on February 15, 1926, in the pro-Fascist Italian American newspaper Il Corriere d'America. A month later it also appeared in Italy in the Fascist newspaper L'Impero (March 12, 1926). His letter conveyed his gratitude to the United States for the outstanding personal and professional opportunities that he enjoyed but also vehemently maintained that "no one has felt and continues to feel more than I do the sacrosanct pride and privilege of being born Italian." ${ }^{5}$ In the summer of 1926, news of the Italian ban kept making headlines in America where, possibly because it was a repeated initiative, it was promoted as "persecution." 66 The controversy was still in many people's minds when, after news of his death, newspapers began reporting that his films were being exhibited again in Rome following the Duce's decision to end the boycott after reading Valentino's public letter. ${ }^{67}$

In America, Valentino's sudden death had an even more radical impact, particularly among Fascist authorities and in the patriotic Italian American press. From the very day of his passing, nationalist newspapers such as Il Progresso Italo Americano and Il Corriere d'America emphatically praised the Italian actor. ${ }^{68}$ The most patriotic of the ethnic press filled its front pages with daily reports on the number of people crowding outside Campbell's or on the Hollywood personalities paying homage to the Italian divo and participating in his funeral. ${ }^{69}$ Ex post facto patriotism was to be expected, but the quick about-face of the New York-based Fascists was also impressive. Had Mussolini actually ordered his loyal Blackshirts to pay homage to Valentino and do so publicly?

First the facts: In the evening of August 23, a group of Italian American Fascists set out to post an honor guard around the film star's flowered bier at Campbell's funeral home. They gained access to the funeral home by declaring that Mussolini himself had given such instructions-a claim that the Italian authorities soon denied. Italian American members of the Anti-Fascist League, who claimed to know the thirty-one-year-old Divo's personal opposition to the regime, tried to prevent the Blackshirts' physical and ideological appropriation of his body and fame. ${ }^{70}$ A fight erupted. Eventually, Fascist representatives were able to stand guard in an official, military fashion over his corpse and lay a wreath at his side with the inscription "From Benito Mussolini," thus saluting Valentino as one of them (figure 29). At midnight they were asked to leave. The morning papers spread images of the startling display. ${ }^{71}$

The archival evidence sheds evidence on this issue. ${ }^{72}$ On August 26, 1926, three days after Valentino's death, several things happened. In the morning, the 




Le camicie nere di New York posano i fiori del Duce sulla bara di Rodolfo Valentino

FIGURE 29. New York Blackshirts pose with the Duce's wreath for Rodolfo Valentino's coffin. Il Grido della Stirpe [The Roar of the Race], August 28, $1926,1$.

front page of the New York Times reported on the clash between Fascists and anti-Fascists at Campbell's. Quite alarmingly for Italian government officials, the New York Times quoted Pietro Allegra, secretary of the Anti-Fascist Alliance, denying the Fascists the right to post guard at the actor's bier. The article included a long excerpt of Allegra's telegram to Ullman in which he denounced the behavior of the American Fascists as an "insult to the memory of the great artist, who in life manifested his opposition to the anti-democratic policies of Mussolini."”3 Possibly even more distressing was the contradiction captured by the New York Times between the American Fascists' claim that they were operating "on instructions from Mussolini" and an Associated Press dispatch from Rome that suggested that Mussolini had not given any such order. 
Then the Italian embassy got involved. In a letter to Ambassador Giacomo De Martino on the same day, the consul informed him that he had just sent a telegram to Mussolini upon the request of Count Paolo Ignazio Maria Thaon di Revel, a noble figure and naval commander who in the fall 1924 had been sent to New York on a difficult mission. His job was to organize the politically dangerous Fasci Italiani all'estero, or Fascists abroad, into the more disciplined and reliable Fascist League of North America (FLNA). Thaon di Revel had told the consul that he was the person responsible for the Fascist guard at Valentino's funeral home. He had taken the initiative of asking a few individuals to wear their Blackshirt uniforms and place a wreath by Valentino's casket with the inscription, "From Benito Mussolini." His intention was to highlight the "nationality and Italian sentiment" of the fallen actor. In his communication to the consul, Count Revel acknowledged that he had not received any authorization by or on behalf of Mussolini. Since the anti-Fascists were accusing him of having acted alone, Revel feared that the issue was becoming a political one and that, if Mussolini were to deny that he had ever given the order, the count's own authority and that of the regime would be discredited. Revel asked that his action not be retracted. ${ }^{74}$ Two days later, the consul informed the ambassador that Mussolini had responded. "Please inform Count Revel that I approve gesture of sympathy toward Rodolfo Valentino. It is appropriate," Mussolini wrote in a telegraph, but added, "in the future my name ought not be used without my prior authorization."75

\section{PLEBISCITE OF PAIN}

Such postmortem reconciliatory gestures, including the end of any boycott of Valentino films, should not obscure the Divo's and the Duce's ideological differences. In Italy, the dictator's antiegalitarian manliness and ideological virilization-molded on the political and discursive repression of the feminine-was hardly compatible with Valentino's sexually transgressive and ambiguous masculinity. The latter resembled the androgynous decadence of another contemporary male political icon, the by-then-passé poet and writer Gabriele D’Annunzio. Still, in the American context, the two figures presented striking affinities. Emphasizing their differences should not discourage our efforts to identify the function of their commonalities within American culture. To look at Valentino as a celebrity, for instance, his impact on the movie public and fan culture turned out to be one of regimentation, the opposite of the conventional narrative of out-of-control crowds of young women attending his funeral. As such, his untimely death dovetailed with the earlier promotion of his mesmerizing romantic power as well as with his overt antidemocratic stance. For years, Valentino made young American women (and men) stand in line at the box office, buy movie magazines, and return to the movie houses for comparable romantic stories. The coverage of his death and the allegedly spontaneous hysteria it provoked does not reveal the well-regimented 
political economy and publicity of his cinematic celebrity. Instead, it conceals it. When examined closely, we discover that the hysteria was manipulated and the coverage of the funeral often aimed to produce an interclass universality of response-ranging from grief to mere curiosity-evident in images of continuous orderly lines of visitors outside Campbell's. Il Progresso Italo-Americano and Il Corriere d'America captured this (staged) unanimity in terms of a "plebiscite of pain" (plebiscito di dolore) or "universal plebiscite of grief for Valentino" (plebiscito universale di cordoglio per Valentino)..$^{6}$

Even in the end, the transnational star Valentino, through his exotic screen image and the rational and affective activities of publicity men, was capable of turning America's threatening masses into discreet and generally well-behaved film audiences. The public record does not include reports of out-of-control mobs invading the movie theaters that throughout his career exhibited his films; and if they elbowed their way in, once inside, "for one hour and a half they sat spellbound applauding" him. ${ }^{77}$ His spectators were actually identifiable and reliable targets for consumer and political agendas during his life and after. ${ }^{78}$

If the plot of The Sheik and The Son of the Sheik is any indication of his reception, the final destiny of the devoted female protagonist, Diana Majo, is not that of an independent flapper but of the loyal, domesticated partner destined for marriage. With "cave-man love and tenderness," Valentino may have empowered flappers or new women sexually and romantically. American film audiences' unprecedented display of sensual attraction to a foreigner became a familiar trope of reviews and reports. Yet, his iconic popularity did not open up radically subversive possibilities for gender equality (or democracy), on or off screen. Conforming to Hollywood's business and cultural prerogatives, instead, his groundbreaking stardom had a very familiar and conservative ring to it. It remains to be seen whether, when positioned side by side with Mussolini's celebrity, what emerges in both cases is the fungibility of a foreign individual for the growth of domestic institutions of crowd management. 